\title{
PELATIHAN PENULISAN ARTIKEL ILMIAH UNTUK MENJADIKAN GURU SEKOLAH DASAR PROFESIONAL
}

\author{
Rury Rizhardi' ${ }^{1}$ Imelda Ratih Ayu², David Budi Irawan ${ }^{3}$, \\ Moh. Reza Ifnuari ${ }^{4}$, Upy Raudotul Jannah ${ }^{5}$ \\ Program Studi Pendidikan Guru Sekolah Dasar Universitas PGRI Palembang \\ ruryrizhardi@univpgri-palembang.ac.id
}

\begin{abstract}
Abstrak
Kemampuan menulis artikel bagi guru menjadi tuntutan profesinya serta bagi pengembangan karirnya guru wajib memenuhi syarat berupa penulisan Karya Tulis Ilmiah. Keluhan tidak bisa menulis masih saja menjadi hambatan bagi guru untuk menangkap peluang-peluang tersebut, sehingga pengembangan diri dan karirnya berjalan tidak seperti yang diharapkan. Secara umum ada beberapa kendala yang bisa ditemukan sehingga membuat tingkat partisipasi menulis di kalangan guru ini rendah. Selama ini guru lebih banyak disibukkan dengan aktivitas mengajar di kelas sehingga kewajiban membaca untuk pengembangan dirinya menjadi tidak terpenuhi. Keterbatasan ketersediaan bahan bacaan yang bisa menjadi bahan tulisan serta tidak adanya rasa percaya diri dan kurangnya pengalaman untuk menulis. Salah satu cara untuk meningkatkan kemampuan penulisan artikel bagi guru dengan cara memberikan pelatihan serta penyuluhan penulisan artikel. Metode kegiatan ini dilaksanakan dengan pelatihan, penyuluhan, dan pendampingan.
\end{abstract}

Kata kunci: Pelatihan, Artikel Ilmiah, Sekolah Dasar

\section{Abstract \\ Scientific Article Writing Training To Make A Professional \\ Elementary School Teacher}

The ability to write articles for teachers is a professional demand and for career development, teachers must meet the requirements in the form of writing scientific papers. Complaints of not being able to write are still an obstacle for teachers to seize these opportunities, so that their personal and career development does not go as expected. In general, there are several obstacles that can be found so that the level of writing participation among teachers is low. So far, teachers are more busy with teaching activities in class so that the obligation to read for self-development is not fulfilled. Limited availability of reading material that can be used as writing material and lack of self-confidence and lack of experience in writing. One way to improve the ability of writing articles for teachers is by providing training and counseling on article writing. The method of this activity is carried out by training, counseling, and mentoring.

Keywords: Training, Scientific Articles, Elementary School

Artikel disetujui tanggal: 22-01-2022

Corresponden Author:Rury Rizhardiｅ-mail: ruryrizhardi@univpgri-palembang.ac.id

DOI: http://dx.doi.org/10.31851/dedikasi.v5i1.6955 $^{\text {do }}$ 


\section{PENDAHULUAN}

Guru memiliki banyak potensi dan potensi yang dimilikinya akan berkembang secara optimal dengan menulis. Hal ini didukung oleh banyaknya kondisi guru yang memperkuat peluang bagi berkembangnya kemampuan menulis. Pertama, guru selalu berinteraksi dengan ilmu pengetahuan yang bisa menjadi bahan untuk menulis. Kedua, guru selalu berinteraksi dengan siswa dalam pembelajaran di kelas yang bisa menjadi sumber tulisan. Ketiga, guru sering berinteraksi dengan dunia pendidikan dan berbagai kebijakannya yang dinamis yang selalu menuntutnya berpikir, mengeluarkan ide-ide inovatifnya.Keempat, banyaknya peluang lomba menulis, baik yang diselenggarakan Dinas Pendidikan maupun Departemen Agama sebagai instansi yang menaunginya. Kelima, media massa menyediakan banyak rubrik pendidikan yang memungkinkan bagi guru untuk mengekspresikan gagasangagasan inovatifnya.

Banyak peluang menulis ada di depan mata para guru. Akan tetapi, sangat disayangkan peluang-peluang tersebut belum banyak dimanfaatkan oleh guru. Keluhan tidak bisa menulis masih saja menjadi hambatan bagi guru untuk menangkap peluang-peluang tersebut, sehingga pengembangan diri dan karirnya berjalan tidak seperti yang diharapkan. Bahkan, keluhan tidak bisa menulis juga menjadi keluhan Guru Pendidikan Jasmani Olahraga dan Kesehatan yang semestinya lebih dekat dengan dunia tulis menulis.

Munculnya keluhan tidak bisa menulis di kalangan guru tentu saja bukan tanpa sebab. Secara umum ada beberapa kendala yang bisa ditemukan sehingga membuat tingkat partisipasi menulis di kalangan guru ini rendah. Pertama, rendahnya minat membaca dan minat menulis. Aktivitas menulis tidak bisa dilepaskan dari aktivitas membaca. Selama ini guru lebih banyak disibukkan dengan aktivitas mengajar di kelas sehingga kewajiban membaca untuk pengembangan dirinya menjadi tidak terpenuhi.Kedua, keterbatasan ketersediaan bahan bacaan yang bisa menjadi bahan tulisan. Ketiga,tidak adanya rasa percaya diri dan kurangnya pengalaman untuk menulis. Keempat, ketidakpahaman guru atas bekalbekal keilmuan untuk bisa terampil menulis. Kelima, rendahnya motivasi untuk menulis. Tulisan dapat dikelompokkan menjadi karya ilmiah dan karya fiksi. Sesuai istilah,karya ilmiah adalah sebuah karya tulis yang penyusunannya didasarkanpada kajian ilmiah dengan landasan ilmu pengetahuan tertentu. Secara lebih jelas, (Gie, 1992) mengungkapkan bahwa karya ilmiah memiliki kriteria tertentu dalam hal permasalahan, pemaparan, dan susunannya. Kriteria-kriteria tersebut antara 
lain mengetengahkan masalah dalam bidang ilmu tertentu, objektif, rasional dan tidak emosional, berdasarkan fakta, dan tersusun secara sistematik dan runtut (Maryadi, 2010)

Pemaparan karya ilmiah harus sistematis, logis, dan cermat dalam segala aspek, termasuk aspek bahasa. Bahasa yang digunakan adalah bahasa yang baik dan benar, baik sesuai situasi dan benar sesuai kaidah baku dan dengan peristilahan yang konsisten.Ragam bahasa ilmiah memiliki beberapa ciri, di antaranya menggunakan ragam baku, lugas (denotatif), memperhatikan pilihan kata yang tepat, menggunakan kalimat yang efektif, dan mengacu pada Ejaan yang Disempurnakan. Susunan karya tulis ilmiah harus mengikuti pola atau sistematika ilmiah, tertib, dan bentuk yang lazim berlaku dalam dunia keilmuan atau masyarakat ilmuwan.Beberapa contoh karya ilmiah diantaranya makalah atau paper, laporan penelitian, karya tulis, skripsi, tesis, dan disertasi.

Dilihat dari organisasinya, sebuah karya ilmiah terdiri dari dua unsur, yaitu isi dan format/bentuk. Isi terkait dengan ide yang dikembangkan dalam sebuah tulisan, sedangkan format atau bentuk terkait dengan teknik penyajiannya (misalnya pemilihan katanya, pembentukan kalimatnya, pengembangan paragrafnya, alur tulisannya, dan sebagainya). Kedua hal ini saling berhubungan dan menentukan kualitas tulisan.

Seperti dikemukakan di
atas, bahwa dilihat dari
organisasinya, karya ilmiah
terdiri dari dua unsur yaitu isi
dan bentuk (format). Isi
berkaitan dengan ide dan tema yang menjadi pokok permasalahan. Ide tulisan terkait dengan tema dan gagasan yang dituangkan pengarang dalam tulisan. Beberapa hal yang harus dipertimbangkan dalam memilih ide tulisan/karangan ilmiah adalah menarik perhatian, sempit dan terbatas, ada data dan fakta yang objektif, dan memiliki sumber acuan atau pustaka. Proses penulisan ilmiah biasanya dimulai dengan pengamatan dan evaluasi secara menyeluruh dari karya karya yang pernah ada (Khisbiyah, 2000). Dari sini, calon penulis dituntut banyak membaca agar memperoleh ide yang akan dituangkan dalam tulisannya. Membaca memang merupakan modal utama dalam penggalian ide. Dengan kata lain, proses penulisan karya ilmiah meliputi tiga tahap, yaitu pra penulisan (berhubungan dengan ide atau gagasan yang akan ditulis), membuat draf tulisan dan merevisi tulisan.

Pembuatan draf penulisan dan revisi penulisan diperlukan pemahaman tentang format tulisan. Format tulisan karya ilmiah atau yang sering disebut anatomi karya ilmiah memiliki gaya tersendiri yang berbeda dengan karya tulis lainnya. Bahkan format seringkali menjadi ciri khas dari masing- 


\section{V/AHANA DEDIKASI}

masing media penyajinya, misalnya format karya ilmiah untuk prosiding berbeda dengan format karya ilmiah yang dipublikasikan di suratkabar. Oleh karena itu, sebelum menulis ada baiknya mempelajari juga pola penyajian, susunan, kebiasaan dan petunjuk lain dari media yang akan dituju. Namun demikian, ada format umum yang dipatuhi secara bersama-sama, seperti ketentuan judul, ketentuan abstrak, pendahuluan, permasalahan, metodologi, pembahasan dan referensi. Masing-masing bagian tersebut perlu dipelajari secara cermat agar memperoleh hasil tulisan ilmiah yang maksimal.

\section{BAHAN DAN METODE}

Kegiatan ini dilaksanakan dalam bentuk Pelatihan dan Workshop dan pendampingan. Penulisan Artikel Ilmiah Kegiatan dilaksanakan pada tanggal 8 Desember 2021. Objek dari kegiatan ini adalah seluruh guru Sekolah Dasar 187. Dan diharapkan seluruh peserta perlu mengetahui dan dapat mengaplikasian serta bisa menulis artikel.

\section{HASIL DAN PEMBAHASAN}

Hasil kegiatan pengabdian kepada masyarakat ini di laksanakan dan bentuk pelatihan dan pendampingan yang diikuti $90 \%$ guru di Sekolah
Dasar 187 Kota Palembang. Materi pelatihan meliputi ; 1) Pengantar Karya Tulis Ilmah 2) Kiat Menuyusun Karya Tulis Ilmiah 3) Cara Mempublikasikan karya Tulis Ilmiah.

Materi tersebut diberikan untuk membangun konsep pemahaman serta motivasi kepada guru untuk dapat menulis karya ilmiah. Pada pelaksanaan kegiatan para guru dapat menyusun sebuah artikel berdasarkan data yang sudah mereka miliki. Pada saat kegiatan pendampingan guru juga sudah dapat melakukan submit artikel pada laman jurnal tertentu yang sudah kami siapkan.

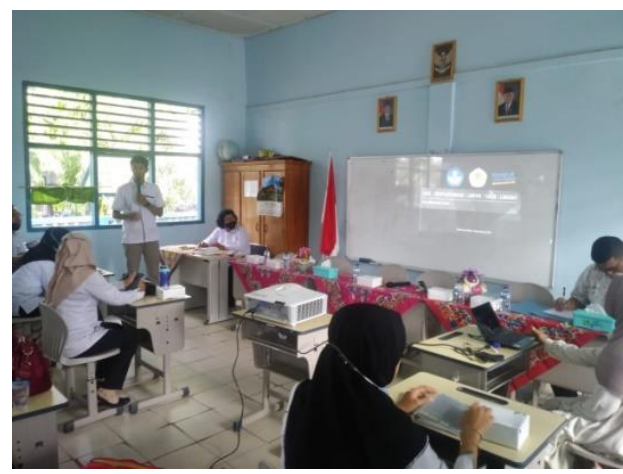

Gambar 1. Pelatihan Penulisan Artikel

Guru profesional yang layak diapresiasi tinggi itu adalah guru yang menjadi pelaku aktif sebuah proses pembentukan ilmu pengetahuan (Eni Nur Aisyah, Putri Mahanani, 2017). Aktifitas menulis melibatkan unsur penulis sebagai penyampai pesan, pesan atau isi tulisan, saluran atau media tulisan danpembaca sebagai penerima pesan. 


\section{WAHANA DEDIKASI}

\section{KESIMPULAN}

Dari hasil kegiatan pengabdian dalam bentuk pelatihan di SD187 Kota Palembang kepada guru yang dilaksanakan disekolah tersebut dapat disampaikan beberapa hasil yaitu: 1) Antusias para guru yang tinggi dalam menyimak dan mengikuti kegiatan dari awal hingga akhir; 2) Para Guru aktif selama kegiatan, yaitu dari banyaknya pertanyaan yang diajukan kepada pemateri tentang topik yang dipaparkan; 3) Para guru memiliki pengetahuan baru serta sudah dapat menulis artikel dan mengetahui situs-situs untuk mempublikasikan artikel ilmiah mereka.

\section{DAFTAR PUSTAKA}

Eni Nur Aisyah, Putri Mahanani. (2017).

PELATIHAN MENULISAN

ARTIKEL ILMIAH BAGI

GURU SEKOLAH DASAR

DAN TAMAN KANAK-

KANAK KECAMATAN

TAJINAN KABUPATEN

MALANG. ABDIMAS

PEDAGOGI.

Gie, T. L. (1992). Pengantar Dunia

Karang Mengarang. Yogyakarta: Liberty.

Khisbiyah, Y. (2000). Melawan

Kekerasan Tanpa Kekerasan.

Yogyakarta: Pustaka Pelajar.

Maryadi. (2010). Pedoman Penulisan

Skripsi FKIP . Surakarta:

Universitas Muhammadiyah

Surakarta. 